\title{
UJI AKTIVITAS ANTIMIKROBA KARANG LUNAK Dendronephtya sp., YANG DIKOLEKSI DARI DESA TUMBAK KECAMATAN PUSOMAEN, KABUPATEN MINAHASA TENGGARA TERHADAP Escherichia coli, Staphylococcus aureus, dan Candida albicans
}

\author{
Gloria Ekaputri Silap ${ }^{1)}$, Defny Wewengkang ${ }^{1)}$, Henki Rotinsulu ${ }^{1)}$ \\ ${ }^{1}$ Program Studi Farmasi FMIPA UNSRAT Mannado, 95115
}

\begin{abstract}
Soft coral Dendronephtya sp., living in the waters of coral reefs that are rather deep, at depths below 10 meters, grow attached to a hard substrate, protected under lumps of living coral or dead coral. This study aims to determine the antimicrobial activity of soft coral Dendronephtya sp., collected from the waters of Tumbak Village, Pusomaen District, Southeast Minahasa Regency, against Escherichia coli, Staphylococcus aureus and Candida albicans. Dendronephtya sp., extracted by maceration method using $96 \%$ ethanol solvent, fractionation using liquid-liquid partition method with n-hexane, chloroform and methanol solvent, and the testing of antimicrobial activity using the Kirby Bauer diffusion method. The results showed that ethanol extract of soft corals (Dendronephtya sp.), $n$-hexane fraction had inhibition of $8 \mathrm{~mm}$ against Escherichia coli bacteria, $7 \mathrm{~mm}$ against Staphylococcus aureus while Candida albicans had very good activity in n-hexane fractions of n-hexane. $9.3 \mathrm{~mm}$, so it can be recommended as an antimicrobial.
\end{abstract}

Keywords : Antimicrobial, Candida albicans, Escherichia coli, Soft Coral (Dendronephtya sp.), Staphylococcus aureus.

\begin{abstract}
ABSTRAK
Karang lunak Dendronephtya sp., hidup di perairan terumbu karang yang agak dalam, pada kedalaman di bawah 10 meter, tumbuh melekat di dasar yang keras, terlindung di bawah bongkahan karang hidup atau karang mati. Penelitian ini bertujuan untuk mengetahui adanya aktivitas antimikroba dari karang lunak Dendronephtya sp., yang dikoleksi dari perairan Desa Tumbak Kecamatan Pusomaen Kabupaten Minahasa Tenggara terhadap Escherichia coli, Staphylococcus aureus dan Candida albicans. Dendronephtya sp., diekstraksi dengan metode maserasi menggunakan pelarut etanol 96\%, fraksinasi menggunakan metode partisi cair-cair dengan pelarut n-heksan, kloroform dan metanol, dan pengujian aktivitas antimikroba menggunakan metode difusi agar Kirby Bauer. Hasil penelitian menunjukkan bahwa ekstrak etanol karang lunak (Dendronephtya sp.) Fraksi karang n-heksan memiliki daya hambat sebesar $8 \mathrm{~mm}$ terhadap bakteri Escherichia coli, $7 \mathrm{~mm}$ pada Staphylococcus aureus sedangkan Candida albicans aktivitas yang sangat baik terjadi pada fraksi dan ekstrak nheksan sebesar 9,3 mm, sehingga dapat direkomendasikan sebagai antimikroba.
\end{abstract}

Kata Kunci : Antimikroba, Candida albicans, Escherichia coli, Karang Lunak (Dendronephtya sp.), dan Staphylococcus aureus 


\section{PENDAHULUAN}

Terumbu karang merupakan bagian dari ekosistem laut yang penting karena menjadi sumber kehidupan bagi keanekaragaman biota laut. Di dalam ekosistem terumbu karang ini pada umumnya hidup lebih dari 300 jenis karang, 200 jenis ikan dan berpuluh-puluh jenis moluska, crustacea, sponge, alge, lamun serta biota lainnya. Terumbu karang memiliki manfaat untuk menjaga kestabilan kondisi ekologi perairan laut, antara lain sebagai habitat, tempat memijah, dan tempat berlindung bagi berbagai jenis hewan (Dahuri, 2000).

Berbagai penelitian menunjukan bahwa biota laut memiliki potensi yang sangat besar dalam menghasilkan senyawa-senyawa aktif yang dapat digunakan sebagai bahan baku obat. Sejak tahun 1980-an, perhatian dunia pengobatan mulai terarah ke biota laut yang diketahui dapat menghasilkan senyawa aktif (Ismet, 2007).

Dendronephtya sp., hidup di perairan terumbu karang yang agak dalam, pada kedalaman di bawah 10 meter, tumbuh melekat di dasar yang keras, terlindung di bawah bongkahan karang hidup atau karang mati. Kadang-kadang ditemukan di dalam gua kecil atau di celah lereng terumbu yang curam dan membentuk koloni seperti pohon kecil. Ukuran maksimum pohon dengan cabangnya secara keseluruhan tidak lebih dari $30 \mathrm{~cm}$. Hal yang unik, hewan ini memiliki batang berwarna putih transparan dan mudah sobek. Karena itu sepanjang tubuhnya disokong oleh deretan duri-duri kecil yang disebut spikula, dan jelas kelihatan dengan mata. Bagian atas batang terdapat kumpulan polip yang bergerombol dan identik dengan mahkota pohon atau dahan dengan daun yang berwarna-warni baik jaringan tubuh maupun spikulanya. Bagian mahkota inilah yang bila dipegang terasa tajam karena mengandung sejumlah spikula kecil dan besar yang menonjol keluar. Selain menambah keindahan bentuk karang lunak ini, spikula juga berfungsi sebagai alat penangkal, terhadap serangan musuh yang akan memangsanya (Manuputty, 1996).

\section{METODOLOGI PENELITIAN \\ Bentuk Penelitian}

Jenis penelitian ini merupakan penelitian eksperimental laboratorik dengan menguji aktivitas antimikroba ekstrak karang lunak (Dendronephtya sp) yang dikoleksi dari perairan

\section{Waktu dan Tempat Penelitian}

Pengambilan sampel dilakukan

di Perairan Desa Tumbak Kecamatan Pusomaen, Kabupaten Minahasa Tenggara. Preparasi Sampel, Pengujian dan pengamatan dilakukan di Laboratorium Lanjut Program Studi Farmasi Fakultas Matematika dan Ilmu Pengetahuan Alam, Universitas Sam Ratulangi Manado. Penelitian ini dilaksanakan pada bulan Mei 2019 - Juli 2019.

\section{Alat dan Bahan}

\section{a. Alat}

Alat yang digunakan dalam penelitian ini yaitu masker, sarung tangan, gunting, tabung oksigen, scuba diving, zipper lock bag, botol $600 \mathrm{ml}$, talenan, cool box, pisau, Erlenmeyer (Pyrex), corong, rotary evaporator, timbangan analitik, corong pisah, gelas ukur, gelas kimia (Pyrex), cawan petri, autoklaf, pinset, pembakar spritus, magnetic stirrer, pipet tetes, micro tubes, hot plate, batang pengaduk, Laminar air flow, rak tabung reaksi, tabung reaksi, lemari pendingin, inkubator, cakram (paper disc), mikropipet, mistar berskala, kertas label, spidol permanen.

\section{b. Bahan}

Bahan- bahan yang digunakan pada penelitian ini yaitu karang lunak Dendronephtya sp, Staphylococcus aureus, 
Escherichia coli, Candida albicans, aquades, etanol, n-heksan, kloroform, metanol, pepton, ekstrak daging (meat extract), natrium klorida, nutrient agar, kloramfenikol (paper disc), kertas label, spidol permanen, kertas saring, kapas, aluminium foil dan tissue.

\section{Prosedur Penelitian}

\section{Pembuata Estraksi}

Karang lunak (Dendronephtya sp.) 530 g d maserasi sebanyak 3 kali. Sampel yang sudah dipotomg kecil-kecil dimasukan kedalam botol lalu direndam dengan larutan etanol 96\% selama 1x24 jam. Kemudian sampel disaring menggunakan kertas saring menghasilkan filtrat 1 dan debris 1 . Debris 1 kemudian ditambah dengan larutan etanol lalu ditutup dengan aluminium foil dan dibiarkan selama 1×24 jam, sampel tersebut disaring menggunakan kertas saring menghasilkan filtrat 2 dan debris 2. Debris 2 kemudian ditambah dengan larutan etanol lalu ditutup dengan aluminium foil selama 1x24 jam, sampel tersebut di lalu disaring menggunakan kertas saring menghasilkan filtrat 3 dan debris 3. Filtrat 1, 2, dan 3 dicampur menjadi satu kemudian disaring, lalu diuapkan menggunakan oven hingga diperoleh ekstrak kental etanol.

\section{Pembuatan Fraksinasi}

Ekstrak kental etanol karang lunak (Dendronephtya sp.) sebanyak $3 \mathrm{~g}$ dimasukkan dalam Erlenmeyer, dilarutkan dengan campuran metanol : air $\left(\mathrm{MeOH}: \mathrm{H}_{2} \mathrm{O}\right)(80: 20)$ sebanyak $100 \mathrm{~mL}$. Setelah sampel larut, dimasukkan kedalam corong pisah lalu ditambahkan pelarut n-heksan dengan jumlah yang sama, setelah itu dikocok berulangkali sampai homogen. Dibiarkan sampel sampai terbentuk lapisan metanol : air $\left(\mathrm{MeOH}: \mathrm{H}_{2} \mathrm{O}\right)$ dan n-heksan. Masing-masing lapisan ditampung dalam wadah yang berbeda. Lapisan n-heksan dievaporasi menggunakan
Oven hingga kering, lalu ditimbang dengan timbangan analitik dan diperoleh fraksi nheksan 3,62 g.

Lapisan $\mathrm{MeOH}: \mathrm{H}_{2} \mathrm{O}$ ditambahkan akuades sebanyak $100 \mathrm{~mL}$ dipartisi dengan pelarut kloroform dengan perbandingan 1:1 v/v dalam corong pisah, lalu dikocok berulangkali sampai homogen. Dibiarkan sampai terbentuk dua lapisan yaitu lapisan $\mathrm{MeOH}$ dan kloroform. Masing - masing lapisan ditampung dalam wadah yang berbeda. Lapisan kloroform dievaporasi menggunakan Oven hingga kering lalu ditimbang dan diperoleh fraksi kloroform 3,66 g. Lapisan $\mathrm{MeOH}$ yang ditampung pada wadah yang lain dievaporasi menggunakan Oven hingga kering lalu ditimbang berat sampel, dan diperoleh fraksi $\mathrm{MeOH}$ 5,05 g. Rendemen-rendemen fraksi dihitung dengan persamaan sebagai berikut :

$$
\begin{gathered}
\text { Rendemen }=\frac{\text { Berat hasil ekstrak }}{\text { Berat ekstraksi awal }} \times 100 \% \\
\text { Rendemen }=\frac{\text { Berat hasil Fraksi }}{\text { Berat fraksi awal }} \times 100 \%
\end{gathered}
$$

\section{Sterilisasi Alat}

Alat-alat dan media yang digunakan dalam penelitian aktivitas antimikroba ini distrerilkan terlebih dahulu dengan menggunakan autoklaf pada suhu $121{ }^{\circ} \mathrm{C}$ selama 15 menit. Pinset disterilkan dengan membakar ujung pinset diatas api langsung (Ortez, 2005).

\section{Pembuatan Media Cair B1}

Ditimbang Pepton 0,5 g, ekstrak daging 0,3 g (meat extract) , Natrium klorida 0,3 g dilarutkan dalam akuades sebanyak $100 \mathrm{~mL}$ menggunakan Erlenmeyer, dikocok sampai homogen. Media yang telah homogen kemudian disterilkan dengan menggunakan autoklaf pada suhu $121{ }^{\circ} \mathrm{C}$ selama 15 menit. Dipipet $1 \mathrm{~mL}$ media cair B1, kemudian masukkan dalam tabung reaksi dan tutup dengan aluminium foil. Media cair B1 siap digunakan sebagai media kultur mikroba (Ortez, 2005). 


\section{Kultur Mikroba}

Mikroba yang sudah dikultur (Escherichia coli, Staphylococcus aureus dan Candida albicans) ditambahkan media cair B1 yang disiapkan sebelumnya sebanyak $100 \mu \mathrm{L}$ kedalam tabung reaksi yang berbeda - beda. Masing - masing tabung reaksi ditutup dengan aluminium foil dan dimasukkan kedalam incubator selama $1 \times 24$ jam dengan suhu $37^{\circ} \mathrm{C}$.

\section{Pembuatan Media Agar B1}

Pepton 0,5 g, ekstrak daging (meat extract) 0,3 g, natrium klorida 0,3 g, agar 1,5 g dan dilarutkan dalam akuades sebanyak 100 $\mathrm{mL}$ menggunakan Erlenmeyer, dikocok sampai homogen. Media yang telah homogen kemudian disterilkan dengan menggunakan autoklaf pada suhu $121{ }^{\circ} \mathrm{C}$ selama 15 menit. Media agar B1 siap digunakan untuk uji aktivitas antimikroba.

\section{Pembuatan Kontrol Positif dan Kontol Negatif}

Kontrol positif dalam pengujian antimikroba ini menggunakan kloramfenikol paper disc. Kontrol negatif yang digunakan dalam penelitian ini yaitu menggunakan pelarut methanol, dengan cara membuat larutan stok metanol dengan mengambil sebanyak $200 \mu \mathrm{L}$ metanol kemudian ditotolkan pada kertas cakram.

\section{Pembuatan Larutan Uji}

Larutan uji dibuat dengan cara melarutkan ekstrak etanol karang lunak (Dendronephtya sp.) sebanyak $1 \mathrm{mg}$ kedalam $200 \mu \mathrm{L}$ metanol sehingga menghasilkan konsentrasi larutan uji sebanyak $250 \mu \mathrm{g} / 50 \mu \mathrm{L}$. Perlakuan yang sama dilakukan untuk fraksi nheksan, fraksi kloroform dan fraksi metanol (Ortez,2005).

\section{Pengujian Aktivitas Antimikroba}

Metode yang digunakan dalam penelitian ini yaitu metode difusi agar (disc diffusion Kirby and Bauer). Aktivitas ini diuji pada mikroorganisme Escherichia coli, Staphylococcus aureus dan Candida albicans.
Pada pengujian aktivitas antibakteri ini, kertas cakram (paper disc) yang digunakan berukuran $6 \mathrm{~mm}$ dengan daya serap $50 \mu \mathrm{L}$ tiap cakram. Kosentrasi yang digunakan pada pengujian ini hanya satu kosentrasi yaitu $250 \mu \mathrm{g} / 50 \mu \mathrm{L}$ pada setiap sampel yang terdiri dari ekstrak kental, fraksi n-heksan, fraksi kloroform, fraksi metanol-air, kontrol positif dan kontrol negatif. Sampel yang telah ditentukan kosentrasinya $250 \mu \mathrm{g} / 50 \mu \mathrm{L}$ ditotolkan pada masing-masing cakram dengan menggunakan mikropipet.

Untuk media agar B1 yang sudah diautoklaf pada suhu $121{ }^{\circ} \mathrm{C}$ selama 15 menit, kemudian dinginkan sampai suhu $40{ }^{\circ} \mathrm{C}$. Tuangkan media agar ke cawan petri, Ambil sebanyak $100 \mu \mathrm{L}$ mikroba yang telah di kultur dalam tabung reaksi, dipipet dan diinokulasi pada media agar dan tunggu sampai media agar mengeras. Masing-masing cawan petri diberi label dan nomor sampel yang sesuai. Letakkan kertas cakram yang telah ditotolkan sampel uji karang lunak (Dendronephtya sp.). Cawan petri lalu diinkubasi selama 1x24 jam pada suhu 37 ${ }^{\circ} \mathrm{C}$ (Ortez, 2005).

\section{Pengamatan dan Pengukuran Zona Bening}

Pengamatan dilakukan dengan mengukur diameter zona hambat yang terjadi pada media dengan menggunakan jangka sorong beralaskan kertas berwarna gelap. Diameter zona hambat yang diukur yaitu daerah jernih yang terbentuk disekitar disk/cakram (tidak ada pertumbuhan bakteri) diukur dari ujung yang satu ke ujung yang lain melalui tengah-tengah disk/cakram atau diukur diameter vertikal dan horizontalnya (Soemarno,2000).

Daerah jernih disekitar cakram menunjukkan kepekaan bakteri terhadap antibiotik atau bahan antibakteri yang digunakan sebagai bahan uji yang dinyatakan dengan diameter zona hambat. Diameter zona hambat diukur dalam satuan millimeter ( $\mathrm{mm}$ ) menggunakkan mistar berskala (Davis and Stoud, 1971) dengan sedikit modifikasi. 
PHARMACONJurnal Ilmiah Farmasi - UNSRAT Vol. 9 No. 1 FEBRUARI 2020 ISSN 2302 - 2493

Klasifikasi zona Hambat menurut Davis dan Stout (1971) dapat lihat pada Tabel 1.

Tabel 1. Klasifikasi zona Hambat menurut Davis dan Stout (1971)

\begin{tabular}{cc}
\hline Diameter Zona Hambat & Respon Hambat Pertumbuhan \\
\hline$>20 \mathrm{~mm}$ & Sangat kuat \\
$11-20 \mathrm{~mm}$ & Kuat \\
$5-10 \mathrm{~mm}$ & Sedang \\
$<5 \mathrm{~mm}$ & Kurang \\
\hline
\end{tabular}

\section{Pengolahan Data dan Analisis Data}

Pengolahan data dilakukan dengan metode penyajian dalam bentuk tabel dan gambar, grafik dan analisis secara deskriptif. Aktivitas antibakteri diukur menggunakan penggaris besi skala millimeter berdasarkan zona hambat yang terbentuk.

\section{HASIL DAN PEMBAHASAN}

\section{Ektrak Karang Lunak (Dendronephtya sp.)}

Ekstraksi adalah proses pemisahan zat dari campurannya dengan menggunakan pelarut tertentu. Ekstraksi terdiri dari beberapa metode di antaranya yaitu metode maserasi. Maserasi merupakan metode ekstraksi sederhana yang sering digunakan (Mukhriani, 2014). Proses maserasi ini dilakukan dengan cara merendam sampel karang lunak (Dendronephtya $\quad$ sp.) sebanyak $3 \times 24$ jam dengan menggunakan larutan etanol $96 \%$. Sebelum maserasi dilakukan, sampel di bersihkan dari kotoran dan dipotong kecilkecil. Pemotongan sampel dilakukan untuk memperluas permukaan sentuh sampel, karena luas permukaan berpengaruh terhadap hasil yang optimal dari proses maserasi. Semakin kecil ukuran sampel maka semakin besar luas permukaannya sehingga memudahkan senyawa aktif yang ada pada karang lunak (Dendronephtya sp.) dapat larut ke dalam pelarut yang digunakan. Pelarut yang digunakan dalam penelitian ini yaitu pelarut etanol 96\%. Menurut Trifani (2012), etanol digunakan sebagai pelarut karena bersifat polar, universal, dan mudah didapat. Beberapa proses ekstraksi yaitu penyaringan dan penguapan menggunakan alat oven. Penyaringan dilakukan dengan menggunakan kertas saring untuk memisahkan sampel karang lunak (Dendronephtya sp.) dengan pelarut etanol yang mengandung senyawa bioaktif. Penguapan pelarut dengan oven dilakukan untuk mempermudah pemisahan pelarut yang digunakan dengan ekstrak sehingga diperoleh ekstrak kental.

\section{Fraksi Karang Lunak (Dendronephtya sp.)}

Fraksinasi adalah proses penarikan suatu senyawa dengan menggunakan beberapa pelarut yang tidak saling bercampur. Senyawasenyawa yang bersifat non polar akan larut dalam pelarut yang nonpolar sedangkan senyawa-senyawa yang bersifat polar akan larut dalam pelarut yang bersifat polar (Sari, 2012).

Pelarut yang digunakan untuk fraksinasi yaitu n-heksan, kloroform, dan metanol. Pelarut n-heksan digunakan untuk menarik senyawa yang bersifat non polar, pelarut kloroform digunakan untuk menarik senyawa yang bersifat semi polar sedangkan pelarut metanol digunakan untuk menarik senyawa-senyawa yang bersifat polar. 
PHARMACONJurnal Ilmiah Farmasi - UNSRAT Vol. 9 No. 1 FEBRUARI 2020 ISSN 2302 - 2493

Tabel 2. Rendemen ekstrak dan fraksi karang lunak (Dendronephtya sp.)

\begin{tabular}{cccc}
\hline No & Sampel & $\begin{array}{c}\text { Rendemen } \\
(\mathbf{\%})\end{array}$ & Warna Sampel \\
\hline $\mathbf{1}$ & Ekstrak Etanol & 3,21 & Coklat kemerahan \\
$\mathbf{2}$ & Fraksi n-Heksan & 0,085 & Bening \\
$\mathbf{3}$ & Fraksi Kloroform & 0,039 & Coklat Pekat \\
$\mathbf{4}$ & Fraksi Metanol & 0,088 & Kuning Kecoklatan
\end{tabular}

$\begin{array}{ll}\text { Aktivitas antimikroba ekstrak dan fraksi } & \text { cakram, ini berarti terjadi pembentukan zona } \\ \text { karang lunak (Dendronephtya sp.) } & \text { hambat di sekitar cakram yang telah ditotolkan } \\ \text { Uji aktivitas antimikroba ekstrak dan } & \text { sampel uji karang lunak (Dendronephtya sp.) } \\ \text { Fraksi n-heksan, fraksi kloroform dan fraksi } & \text { dan pada cakram antibiotik Kloramfenikol } \\ \text { metanol karang lunak (Dendronephtya sp.) } & \text { sebagai control positif. Pada cakram kontrol } \\ \text { terhadap bakteri Escherichia coli, } & \text { negatif tidak terlihat adanya zona hambat. Zona } \\ \text { Staphylococcus aureus dan Candida albicans } & \text { hambat yang terbentuk diukur diameternya } \\ \text { dengan metode difusi agar (Difusi Kirby- } & \text { dengan menggunakan jangka sorong dengan } \\ \text { Bauer) yang telah dimodifikasi. Pengujian } & \text { satuan milimeter (mm). Pengukuran dilakukan } \\ \text { dilakukan dengan mengukur zona hambat pada } & \text { dengan cara mengukur diameter dari ujung } \\ \text { media agar B1 setelah diinkubasi dalam alat } & \text { yang satu ke ujung yang lain melalui tengah- } \\ \text { inkubator selama 1x24 jam. Pertumbuhan } & \text { tengah cakram. }\end{array}$
bakteri setelah inkubasi terlihat menjauhi

Tabel 3. Hasil pengukuran diameter zona hambat ekstrak dan fraksi karang lunak (Dendronephtya sp.) terhadap Escherichia coli.

\begin{tabular}{ccccccc}
\hline Ulangan & \multicolumn{6}{c}{ Diameter zona hambat $(\mathbf{m m})$ terhadap Escherichia coli } \\
\cline { 2 - 7 } & $\begin{array}{c}\text { Ekstrak } \\
\text { EtOH }\end{array}$ & $\begin{array}{c}\text { Fraksi } \\
\text { n-Heksan }\end{array}$ & $\begin{array}{c}\text { Fraksi } \\
\mathrm{CHCl}_{3}\end{array}$ & Fraksi & Kontrol & Kontrol \\
& & & & $(+)$ & $(-)$ \\
I & 8 & 8 & 8 & 7 & & \\
II & 7,5 & 8 & 7,5 & 7 & & \\
III & 7,5 & 8 & 7,5 & 7 & 22 & - \\
Total & 23 & 24 & 23 & 21 & & \\
$\overline{\boldsymbol{X}}$ & 7,7 & 8 & 7,7 & 7 & & \\
\hline
\end{tabular}

Diameter zona hambat ekstrak dan fraksi karang lunak (Dendronephtya sp.) terhadap Escherichia coli yang paling besar dihasilkan oleh fraksi n-heksan yaitu sebesar $24 \mathrm{~mm}$ dengan nilai rata-rata $8 \mathrm{~mm}$, membuktikan bahwa adanya aktivitas antimikroba pada karang lunak (Dendronephtya sp.) yang sedang menurut Daviv and Stout (1971). Hasil pengukuran diameter zona hambat dapat dilihat pada Tabel 3. 
Tabel 4. Hasil pengukuran diameter zona hambat ekstrak dan fraksi karang lunak(Dendronephtya sp.) terhadap Staphylococcus aureus.

\begin{tabular}{|c|c|c|c|c|c|c|}
\hline \multirow[t]{2}{*}{ Ulangan } & \multicolumn{6}{|c|}{ Diameter zona hambat (mm) terhadap Staphylococcus aureus } \\
\hline & $\begin{array}{c}\text { Ekstrak } \\
\text { EtOH }\end{array}$ & $\begin{array}{c}\text { Fraksi } \\
\text { n-Heksan }\end{array}$ & $\begin{array}{l}\text { Fraksi } \\
\mathrm{CHCl}_{3}\end{array}$ & $\begin{array}{l}\text { Fraksi } \\
\mathrm{MeOH}\end{array}$ & $\begin{array}{c}\text { Kontrol } \\
(+)\end{array}$ & $\begin{array}{c}\text { Kontrol } \\
(-)\end{array}$ \\
\hline I & 7 & 7 & 7 & 8 & & \\
\hline II & 6,5 & 7 & 7 & 8 & & \\
\hline III & 6,5 & 7 & 7 & 7 & 18 & - \\
\hline Total & 20 & 21 & 21 & 23 & & \\
\hline $\bar{X}$ & 6,7 & 7 & 7 & & & \\
\hline
\end{tabular}

fraksi karang lunak (Dendronephtya sp.) terhadap bakteri Staphylococcus aureus yang paling besar dihasilkan oleh ekstrak n-heksan yaitu sebesar $21 \mathrm{~mm}$ dengan nilai rata-rata 7 $\mathrm{mm}$, membuktikan bahwa adanya aktivitas
(Dendronephtya sp.) yang sedang menurut Daviv and Stout (1971). Hasil pengukuran diameter zona hambat dapat dilihat pada Tabel 4.

Tabel 5. Hasil pengukuran diameter zona hambat ekstrak dan fraksi karangn lunak (Dendronephtya sp.) terhadap Candida albicans.

\begin{tabular}{|c|c|c|c|c|c|c|}
\hline \multirow[t]{2}{*}{ Ulangan } & \multicolumn{6}{|c|}{ Diameter zona hambat (mm) terhadap Candida albicans } \\
\hline & $\begin{array}{c}\text { Ekstrak } \\
\text { EtOH }\end{array}$ & $\begin{array}{c}\text { Fraksi } \\
\text { n-Heksan }\end{array}$ & $\begin{array}{l}\text { Fraksi } \\
\mathrm{CHCl}_{3}\end{array}$ & $\begin{array}{l}\text { Fraksi } \\
\mathrm{MeOH}\end{array}$ & $\begin{array}{c}\text { Kontrol } \\
(+)\end{array}$ & $\begin{array}{c}\text { Kontrol } \\
(-)\end{array}$ \\
\hline I & 7 & 10 & 6,5 & 6,5 & & \\
\hline II & 7 & 9 & 6,5 & 6,5 & & \\
\hline $\begin{array}{c}\text { III } \\
\text { Total }\end{array}$ & $\begin{array}{c}7 \\
21\end{array}$ & $\begin{array}{c}9 \\
28\end{array}$ & $\begin{array}{c}7 \\
20\end{array}$ & $\begin{array}{c}6,5 \\
19,5\end{array}$ & 18 & - \\
\hline$\overline{\boldsymbol{X}}$ & 7 & 9,3 & 6,7 & 6,5 & & \\
\hline
\end{tabular}

Diameter zona hambat ekstrak dan fraksi karang lunak (Dendronephtya sp.) terhadap Candida albicans yang paling besar dihasilkan oleh ekstrak n-heksan yaitu sebesar $28 \mathrm{~mm}$ dengan nilai rata-rata $9,3 \mathrm{~mm}$. Hasil pengukuran diameter zona hambat dapat dilihat pada Tabel 5.

Berdasarkan hasil pengamatan yang dilakukan terhadap mikroba Escherichia coli, Staphylococcus aureus dan Candida albicans masing-masing sebanyak tiga kali pengulangan memperlihatkan adanya zona hambat yang terbentuk disekitar disk/cakram. Pada fraksi etanol menunjukan adanya aktivitas antimikroba yang terbentuk tetapi hanya kecil, sedangkan pada ekstrak metanol memperlihatkan adanya aktivitas antimikroba terhadap Escherichia coli, Staphylococcus aureus dan Candida albicans. Hal ini ditunjukan dengan terbentuknya zona hambat disekitar cakram sebesar $14 \mathrm{~mm}$ pada Escherichia coli tergolong kuat, $23 \mathrm{~mm}$. Hasil ini menunjukan bahwa fraksi metanol memiliki aktivitas sebagai antimikroba. Pada fraksi 
metanol memperlihatkan aktivitas antimikroba terhadap Escherichia coli, Staphylococcus aureus dan Candida albicans yang tergolong kuat. Hal ini ditunjukan dengan terbentuknya zona hambat disekitar cakram sebesar $18 \mathrm{~mm}$ pada Escherichia coli, $21 \mathrm{~mm}$ pada Staphylococcus aureus $7 \mathrm{~mm}$ dan pada Candida albicans 19,5. Jika dibandingkan dengan ekstrak etanol dan fraksi metanol, fraksi n-heksan memperlihatkan daya hambat yang lebih tinggi. Hal ini ditunjukan dengan aktivitas antimikroba sebesar $8 \mathrm{~mm}$ pada Escherichia coli tergolong kuat, $7 \mathrm{~mm}$ pada Staphylococcus aureus tergolong kuat dan 9,3 mm pada Candida albicans tergolong kuat.

peka dibandingkan dengan bakteri gram negatif. Hal ini disebabkan karena gram positif lebih sensitif terhadap antibakteri sehingga struktur dinding sel yang sederhana mempermudah senyawa antibakteri masuk kedalam sel sedangkan struktur dinding sel gram negatif lebih kompleks.

Kontrol positif memperlihatkan aktivitas antimikroba yang paling besar terhadap mikroba Escherichia coli, Staphylococcus aureus dan Candida albicans. Kloramfenikol merupakan antibiotik yang memiliki spekrum luas terhadap bakteri (Katzung, 2004). Kontrol positif yang memiliki diameter daya hambat lebih besar yaitu $22 \mathrm{~mm}$ pada Escherichia coli, sedangkan pada Candida albicans $18 \mathrm{~mm}$ dan $18 \mathrm{~mm}$ pada Staphylococcus aureus.

Kontrol negatif (methanol) tidak menunjukan terbentuknya zona hambat, hal tersebut menandakan bahwa tidak ada pengaruh pelarut methanol terhadap antimikroba yang diuji.

Aktivitas antikiroba yang terbentuk disekitar disk/cakram ini disebabkan oleh aktivitas senyawa yang terkandung dalam ekstrak dan fraksi karang lunak (Dendronephtya sp). Semakin besar zona hambat yang terbentuk maka semakin kuat
Hasil pengukuran diameter zona hambat digolongkan berdasarkan klasifikasi zona hambat menurut Davis and Stout (Tabel 1). Ekstrak etanol dan fraksi metanol merupakan ekstrak dan fraksi yang efektif terhadap mikroba Escherichia coli dan Candida albicans karena memiliki daya hambat mikroba yang kuat, hal ini dikarenakan gram negatif cenderung peka terhadap antimikroba yang bersifat polar. sedangkan pada ekstrak etanol, fraksi kloroform dan fraksi metanol terhadap bakteri Staphylococcus aureus memiliki kemampuan menghambat mikroba dengan kategori kuat. Hal ini menunjukkan bahwa bakteri gram positif lebih senyawa yang terkandung dalam karang lunak (Dendronephtya sp.) untuk menghambat pertumbuhan mikroba.

\section{KESIMPULAN}

Dendronephtya sp., diekstraksi menggunakan metode maserasi dengan pelarut etanol 96\%, fraksinasi menggunakan metode partisi cair-cair dengan pelarut n-heksan, kloroform dan metanol, dan pengujian aktivitas antimikroba menggunakan metode difusi agar Kirby Bauer. Hasil penelitian menunjukkan bahwa ekstrak etanol karang lunak (Dendronephtya sp.) Ekstrak dan fraksi nheksan memiliki daya hambat sebesar $8 \mathrm{~mm}$ terhadap bakteri Escherichia coli, $7 \mathrm{~mm}$ pada Staphylococcus aureus sedangkan pada Candida albicans aktivitas yang sangat baik terjadi pada fraksi n-heksan sebesar 9,3 mm, sehingga dapat direkomendasikan sebagai antimikroba untuk menjadi kandidat antimikroba

\section{SARAN}

Perlu dilakukan penelitian lebih lanjut terdapat karang lunak (Dendronephtya sp.) dengan metode pengujian yang berbeda dan uji aktivitas lainnya agar dapat mengetahui manfaat lain selain antimikroba. 


\section{DAFTAR PUSTAKA}

Dahuri, R. 2000. Pendayagunaan Sumberdaya Kelautan Untuk Kesejahteraan Masyarakat. LISPI. Jakarta

Davis, W.W and Stout, T.R. 1971. Disc Plate Methods of Microbiological Antibiotic Assay. Microbiology. 22(4): 659-665.

Dwidjoseputro, D. 1978. Dasar-Dasar Mikrobiologi. Djambatan. Jakarta.

Entjang, I. 2003. Mikrobiologi dan Parasitologi untuk Akademi Keperawatan. Citra Aditya Bakti, Bandung.

Frobisher and Fuerst't. 1983. Microbiology in Health and Disease. Edisi XV. Igaku Shoin, Sounders Imternational Edition.

Harborne, J. B. 1987. Metode Fitokimia Penuntun Cara Modern Menganalisis Tumbuhan. Penerbit : ITB. Bandung.

Ismet, M. S. 2007. Penapisan Senyawa Bioaktif Spons Aaptops dan Petrosia sp. dari lokasi yang berbeda. [Skripsi]. Pasca sarjana ITB, Bandung.

Katzung, B. G,. 2004. Farmakologi Dasar dan Klinik. Edisi XIII. Buku 3. Translation of Basic and Clinical Pharmacology Eight Edition. Alih Bahasa oleh Bagian Farmakologi Fakultas Kedokteran Universitas Airlangga. Salemba Medika, Jakarta.

Kayser, F., Bienz KA., Eckert $\mathrm{J}$ and Zinkemengel R, M. 2005. Medical Microbiology. Thieme, New York.

Manuputty, A.E.W., 1996. Pengenalan beberapa karang lunak
(Octocorallia, Alcyonacea), di lapangan. Oseana 21 (4) : 1 - 11.

Octaviani, R. 2007. Profil kromatogram dan aktivitas antibakteri ekstrak etanol rimpang lempuyang gajah (Zingiber zerumbet) terhadap bakteri Escherichia coli in vitro. http:// eprints.undip.ac.id/22663 /1/Rima.pdf. Diakses tanggal 2 Nopember 2018.

Ortez, J.H. 2005. Disk Diffusion testing in manual of antimicrobial susceptibility testing. Marie B. Coyle (Coord. Ed). American society for Microbiology.

Pelczar, M. J. dan E. C. S. Chan. 1988. Dasardasar mikrobiologi. Terjemahan Universitas Indonesia Press. Jakarta.

Post, K W. and Songer, GJ. 2005. MICROBIOLOGY Bacterial and Fungal Agent of Animal Disease. Elsevier Saunders: Philadelphia.

Rosenbach, F.G. 1884. Mikro-Organismen bei den Wund-infection-Krankheiten des Menschen. Wiesbaden, J. F. Bergmann.

Rostinawati, T. 2009. Aktivitas Antibakteri Ekstrak Etanol Bunga Rosella (Hibiscus sabdariffa L.) Terhadap Escherchia coli, Salmonella typhi dan Staphylococcus aureus Dengan Metode Difusi Agar. Penelitian Mandiri: Fakultas Farmasi, Universitas Padjajaran.

Ryan, K.J., Champoux, J.J., Falkow, J.J., Plonde, W.L., Drew, F.C., Neidhardt, dan Roy, C.G. 1994. Medical Microbiology An Introduction to Infection Diseases. Edisi III, 253. Appleiton \& Lange, Connecticut. 
PHARMACONJurnal Ilmiah Farmasi - UNSRAT Vol. 9 No. 1 FEBRUARI 2020 ISSN 2302 - 2493

Sari, Cahyo IP. 2012. Kualitas Minuman Serbuk Kersen (Muntingia calabura L.) dengan Variasi Konsentrasi Maltodekstrin dan Ekstraksi Kayu Secang (Caesalpinia sappan L.). SKRIPSI. Fakultas Teknobiologi Universitas Atma Jaya Yogyakarta, Yogyakart.

Setiabudy, Rianto. 2007. Farmakologi dan Terapi Edisi $V$ ( cetak ulang dengan perbaikan). Jakarta : Gaya Baru

Siregar, R.S. 2005. Penyakit Jamur Kulit. Penerbit Buku Kedokteran EGC, Jakarta.

Siswandono dan Soekardjo. 1995. Kimia Medisinal. Airlangga University Press, Surabaya.

Soemarno. 2000. Depertemen Kesehatan Republik Indonesia Isolasi Dan Identifikasi Bakteri Klinik. Akademi
Analisis Kesehatan Yogyakarta.. Yogyakarta.

Suprihatin, S. 1982. Candida dan Kandidiasis Pada Manusia. Balai Penerbitan Jakarta : Fakultas Kedokteran UI.

Syahrurachman, dkk. 2010. Buku Ajar Mikrobiologi Kedokteran. Jakarta : Binarupa Aksara Publishers 2010

Waluyo L. 2004. Mikrobiologi Umum. Malang: Umm Press.

Warsa, U. C. 1994. Kokus Positif Gram, dalam Buku Ajar Mikrobiologi Kedokteran. Edisi Revisi. Staf Pengajar Fakultas Kedokteran Universitas Indonesia, 103. Binarupa Aksara, Jakarta. 